原著 体表面等時線図（VAT map）による正常および 心室性期外収縮の心室興奮伝播過程の推定

\author{
名古屋大学医学部付属病院椮查部・同第一内科 \\ 林 博史 0 \\ 名古屋大学医学部第一内科 \\ 石川 富久 高見 和秀 小島 春紀 矢部誠太郎
}

大杉茂樹宮地恭一外畑菝

\title{
ESTIMATION OF THE VENTRICULAR ACTIVATION SEQUENCE \\ IN NORMAL AND VENTRICULAR PREMATURE BEAT BY BODY SURFACE ISOCHRONE MAP (VAT MAP)
}

Hiroshi HAYASHI, MD

Department of Clinical Laboratory, Nagoya University Hospital

Tomihisa IshIKAWA, MD, Kazuhide TAKAMI, MD, Haruki KoJIMA, MD,

Seitaro YABE, MD, Shigeki OHSUgI, MD, Kyoichi MiYaCHI, MD and Iwao SotoBata, MD

The First Department of Internal Medicine,

Nagoya University School of Medicine

\begin{abstract}
概要 体表面電位図は，心電図・ベクトル心電図に比して，体表面上に多数の誘導点を有する ので，心蔵の興奮伝播過程を推定するのに非常に有用である，従来からの等電位線図による興 奮伝播過程に関する研究は数多く報告されているが，等時線図による検討は殆どなされていな い. 今回, 体表面電位図から, 各誘導点の心室興奮到達時間(VAT)を求め, これに基づくVAT 等時線困 (VAT isochrone map) を作成して，心室興奮伝播過程を体表面から推定する方法の 有用性の検討を行なつた。対象は，健常成人 50 人，心室性期外收縮を有する患者 150 人，心室ベー シングを行なつている患者25人であつた。 87 誘導点から同時記録された単極誘導心電図に基づ く等電位線図を作成し，これのコンビューター処理によりVAT mapを得た. 正常のVAT map

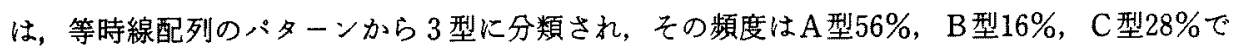
あつた。心室ペースメーカーのVAT mapでは, 電気刺激部位から進展する心室興奮伝播過程が 上く表現され，等電位線図所見亡もよく一致した。先に我々が13個所（右室 4 , 左室 5 , 中隔 4) に発生源を推定した心室性期外收縮のVAT mapでは, 等時線の開始部位により, 期外収縮 の発生源が明らかに示され，またその粗密により，特殊伝導系による伝播，あるいは筋伝導に 上る伝播等が推定された.VAT mapによる心室興奮层播過程の推定は, 等電位線図によるそれ と，よく一致したが，前者は，一枚の図でより直接的に表現でき，極めて有用と考えられた。
\end{abstract}

\section{緒訔}

心室興奮伝播過程を知ることは，心疾患の病態 の理解に極めて重要である.

〔昭和59年 7 月 3 日受稿〕
これは標準12誘導心電図, ベクトル心電図でも, 推定し得るが, 多数の誘導点から構成される電位 図は，興奮伝播に関するより詳細な情報を提供す る.

こうした目的に，体表面電位図が非常に優れて 
いることは, 動物実験による証明, 理論的考察の 裏付け等により, 既に明らかにされている.

臨床的にも，電位図が応用されるようになつて から，ほぼ20年経過し，これまでに電位図による 種々の心疾患の興奮伝播過程に関する報告が, . 数 多くなされてきだ) .

著者らも，等電位線図 (isopotential map)によ る心室性期外収縮 (VPB) の発生源を, 心室各部 位のペースメーカー刺激時の電位分布所見から推

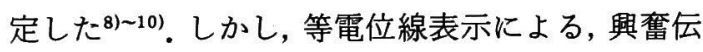
播の判定は, 多数の瞬時の電位図を観察する必要 があるなど，必ずしも容易でない場合が少なくな い.

一方, 電位図から各誘導点毎の, 心室興奮到達 時間 (ventricular activation time, VAT) を求 め, これに基づいて作成されたVAT map(等時線 因）は，興奮伝播過程を 1 枚の図で, より直接的 に表現して拉り，その推定に有用性が高いと考え られる。

そこで, 正常と各種心室期外収縮 (VPB) およ び心室ペーシングのVAP mapを作成して, おの おの等電位線図の所見と対比してその有用性の検 討を行なつた。

\section{対象・方法}

対象は， 3 群に分けられ，第 1 群は，健常成人 50 人（男 42 人，女 8 人）で年令は 20 才から 69 才， (36.5 4 .3才, 平均土標準偏差, 以下同様) であ つた.

第 2 群は，心室性期外収縮 (VPB) を有する患 者 150 人（男 79 人, 女 71 人), 年令は 3 才から 81 才 (45.6士7.6才)であつた。 なお，これらのVPBの 発生源は，既に等電位線図により推定されている 例である ${ }^{8 / 9) . ~}$

第 3 群は，心室ペーシングが施行されている患 者 30 人 (男 18 人, 女 12 人), 年令は 8 才から 69 才 (45.2士3.9才) であつた。

ペーシング部位は，右室心尖部心内膜14例，同 心外膜 8 例, 右室流入路 2 例, 左室心尖部心外膜 3 例, 左室後壁基部（経冠静脈洞） 3 例であつた. 方法は, 87 誘導点から同時記録された単極誘導 心電図を基にして，中日電子社製mapper HPM 6500を用いて等電位線を作成した ${ }^{11)}$.

VAT mapは，日本電子社製ミーコンピーー ター980Bを用て, 各誘導点において, QRS開始か ら，R波の頂点までの時間をventricular activation time (VAT) として求め, 同じ時間を示した 誘導点を結んで作成した。

なお，QSパターンの場合は, VATは０として処 理した。またRSR'のように, late RのあるQRS波 の場合は, 便宜的に RのみのVATを採用した.

\section{結 果}

\section{I. 健常成人}

正常の等電位線図では，心室興奮開始と共に， 右胸部において, 負電位が増大するに従つて, 零 線および極大が次第に, 左胸部から左背部へと移 動した（図 1).

また，興奮初期 $(28 \mathrm{msec})$ に胸部中央の極小に 対向する零線および正電位領域が僅かに陥凹して

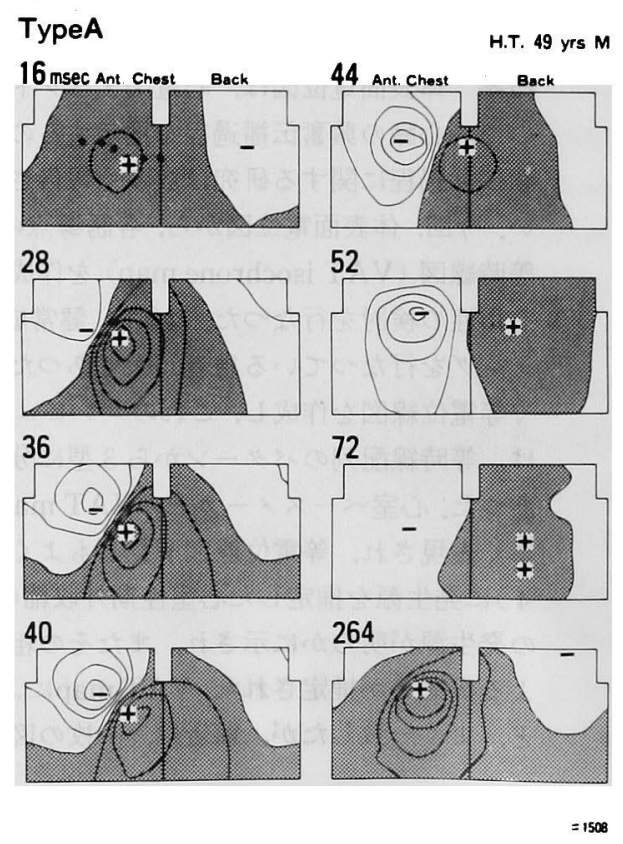

図 1. 健常成人の等電位線図, 各フレームの左半分は 前胸部, 右半分は背部, 灰色部分は正領域, 白色部分 は負領域, 胸部の 6 個の点は $\mathrm{V}_{1} \sim \mathrm{V}_{6}$ の位置. 等電位線 は $400 \mu \mathrm{V}$ 毎, 十は極大, 一は極小. 72msecまではQRSで あり, $264 \mathrm{msec} は \mathrm{~T}$ 波のピーク時点を示す. 
おり，いわゆるniche形成が認められた。

264msecは, 再分極過程でT波の頂点に拈ける 電位分布である.

健常人のVAT mapは, A, B, Cの 3 型に分類す ることができた. Type A (図 2 上段)の等時線は, 右胸部から始まり左胸部に向かつて, 32msecをで は比較的密に，斜めに描かれた。ついで，32〜44 msecでは左側胸部および左背部において粗とな ク，52msecで背部上方にて終結した.

本例は，図 1 の症例と同一人のものであり，等 時線の経時的推移は, 等電位線図に打ける右胸部 にみられる零線の動き扣よび極大の軌跡に極めて よく類似していた。

Type B (図 2 中段) の等時線は，左肩あるいは 左胸部上方領域から始まり, ほぼ水平に密集して
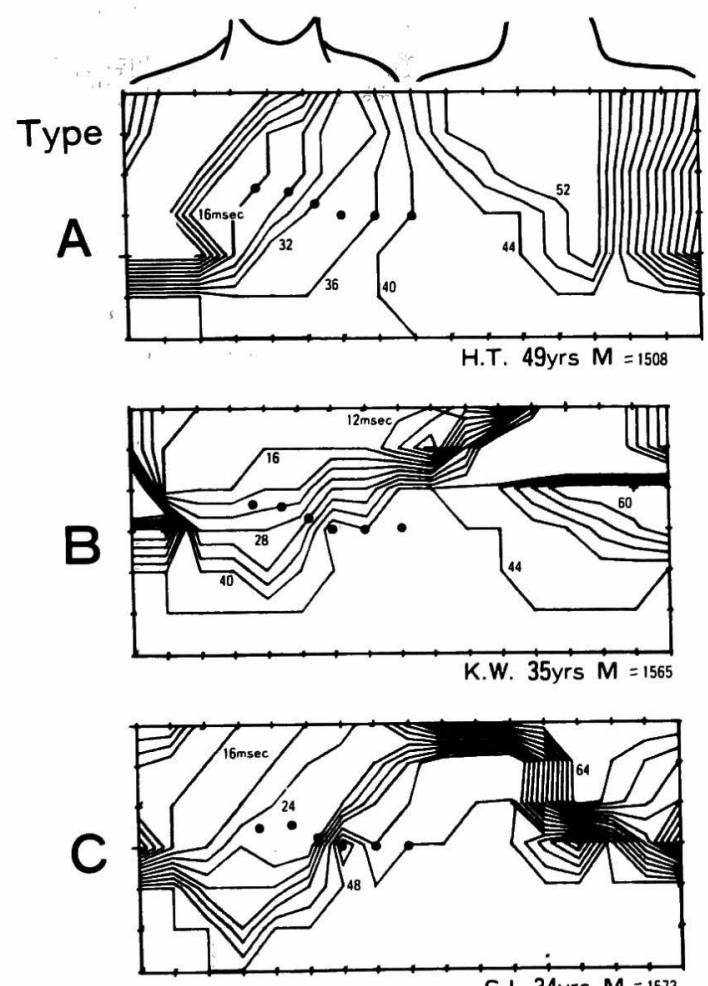

S.I. 34 yrs $M=1573$

因 2. 健常成人の等時線図はA，B，Cの 3 型に分類さ れた。

$\mathrm{A}$ 型の例は図 1 の例と同一症例である。等時線間隔 は4msec.
表 1. VAT and electrical axis in normals

\begin{tabular}{|c|c|c|c|c|c|c|c|c|}
\hline Type & $\begin{array}{l}\text { No. of } \\
\text { Cases }\end{array}(\%)$ & $\begin{array}{l}\text { VAT } \\
V_{1}\end{array}$ & $v_{2}$ & $v_{3}$ & $v_{4}$ & $V_{5}$ & $V_{6}$ & $\begin{array}{c}\text { Electrical } \\
\text { Axis }\end{array}$ \\
\hline A & $28(56.0)$ & $\begin{array}{l}22.8 \\
(6.0)\end{array}$ & $\begin{array}{l}26.0 \\
(6.7)\end{array}$ & $\begin{array}{l}31.1 \\
(7.5)\end{array}$ & $\begin{array}{l}40.2 \\
(5.9)\end{array}$ & $\begin{array}{r}41.3 \\
(5.5)\end{array}$ & $\begin{array}{l}42.3 \\
(5.3)\end{array}$ & $\begin{array}{c}53.8 \\
(16.1)\end{array}$ \\
\hline$B$ & $8(16.0)$ & $\begin{array}{c}24.6 \\
(3.2)\end{array}$ & $\begin{array}{l}24.7 \\
(4.1)\end{array}$ & $\begin{array}{l}27.6 \\
(3.5)\end{array}$ & $\begin{array}{l}40.6 \\
(5.4)\end{array}$ & $\begin{array}{l}41.7 \\
(4.7)\end{array}$ & $\begin{array}{l}43.4 \\
(4.0)\end{array}$ & $\begin{array}{c}83.1 \\
(8.8)\end{array}$ \\
\hline C & $14(28.0)$ & $\begin{array}{l}22.9 \\
(5.7)\end{array}$ & $\begin{array}{l}27.7 \\
(4.5)\end{array}$ & $\begin{array}{l}32.3 \\
(4.9)\end{array}$ & $\begin{array}{c}43.6 \\
(5.5)\end{array}$ & $\begin{array}{c}45.8 \\
(5.5)\end{array}$ & $\begin{array}{r}46.6 \\
(5.5)\end{array}$ & $\begin{array}{c}55.4 \\
(21.7)\end{array}$ \\
\hline Total & $50(100)$ & $\begin{array}{l}23.1 \\
(5.7)\end{array}$ & $\begin{array}{c}26.2 \\
(6.0)\end{array}$ & $\begin{array}{c}30.8 \\
(6.6)\end{array}$ & $\begin{array}{l}41.1 \\
(6.0)\end{array}$ & $\begin{array}{c}42.6 \\
(5.7)\end{array}$ & $\begin{array}{l}43.6 \\
(5.5)\end{array}$ & $\begin{array}{c}59.1 \\
(20.0)\end{array}$ \\
\hline
\end{tabular}

Mean
(SD)

胸部下方に向かつたが, $44 \mathrm{msec}$ では, 左側胸部下 方の広範な領域に拡がり, 60mseck背部中央で終 了した。

Type C (図 2 下段)は，等時線の開始が右肩と， 左肩領域の 2 個所に認められ, Type A, B両者の 混合型のようであつた. 出現頻度は, Type Aは28 例 (56\%), Type Bは 8 例 (16\%), Type Cは14例 （28\%）であつた（表 1).

VAT mapkおいて, 等時線が標準 12 誘導心電 図の $\mathrm{V}_{1}$ から $\mathrm{V}_{6}$ の誘導点を通過する時間を求め, 各 点のVATを検討した (表 1) (平均土標準偏差).

$\mathrm{A} ， \mathrm{~B}, \mathrm{C}$ 型いずれも大きな差はなく, 全体の平均 で, $\mathrm{V}_{1}$ から $\mathrm{V}_{3}$ が, 23.1msecから $30.8 \mathrm{msec} の$ 間に, $\mathrm{V}_{4}$ から $\mathrm{V}_{6}$ が，41.1msecから43.6msecの間に分布 した。標準12誘導心電図から求めた電気軸は,

Type AとType Cに比して, Type Bは83.1と垂 直位の傾向を示した（表 1 ）.

\section{nicheの出現時間}

各Type毎のniche出現時間を等電位線で検討し

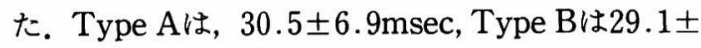

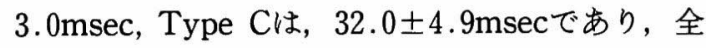

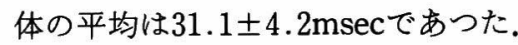

また，おの拉ののTypeにおいてniche出現のみ られた誘導点のVATを検討した。

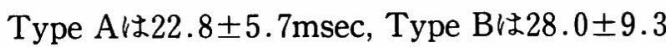

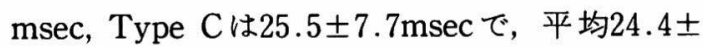
$7.3 \mathrm{msec}$ あ゙り, Type Bを除いて，等電位線図で みられたniche出現時間より6〜 7 $\mathrm{msec}$ 早かつた。

II. 心室ペーシング

右室心尖部心内膜ペーシングの等電位線図（図 

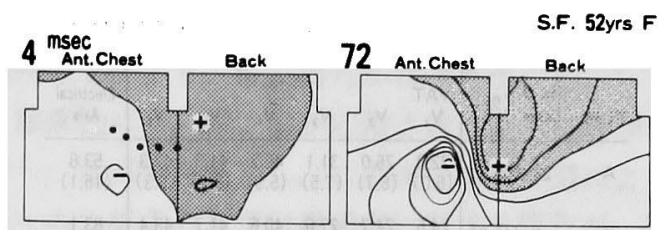

20

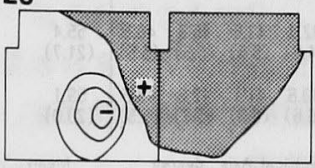

100

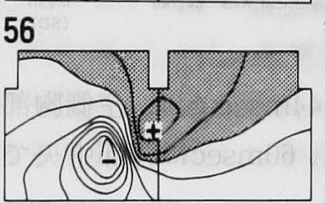

116

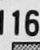

\section{6}

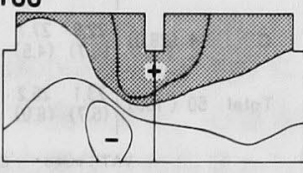

-
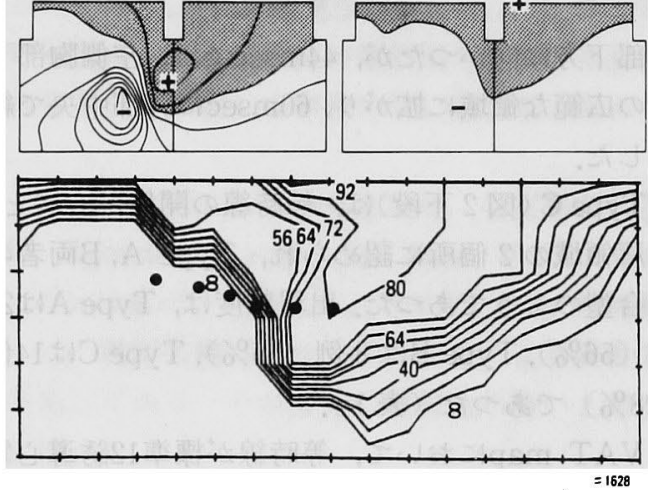

図 3，右室心尖部心内膜ペーシンクの等電位線図(上) 乙等時線图 (下). 等時線間隔は $8 \mathrm{msec}$ (以下同じ).

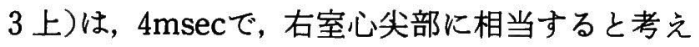
られる領域に極小が出現した，時間経過と共に，

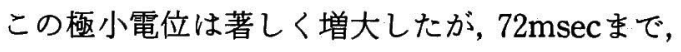
その位置は殆ど変らず, 極大は, 左側胸部にて電 位を増した. $100 \mathrm{msec}$ 以後は, 負領域が下方にまわ り込み, 正領域は左肩領域に退縮した。

本例のVAT map (図 3 下) では, 等時線は8 msecで右胸背部の下方に拆がり, ほぼ同じ等時線 配列が密集して左肩領域に進展した。

右室心尖部心外膜ペーシングの等電位線図（図 4 上)では, $8 \mathrm{msec} て ゙ は$ 極小が右室心尖部に相当す る領域に出現し, 興奮初期 $(8 \sim 48 \mathrm{msec})$ には, 負 領域が胸背の下方を占めた。興奮中期以後 (68 156msec) Kは, 次第に負領域が右胸部全体 に拡がり, 正領域は背部全体を占めた。

本例のVAT map（図 4 下）では，等時線が8 mseck胸部下方に出現し, $24 \mathrm{msec}$ 以後は, 左側胸
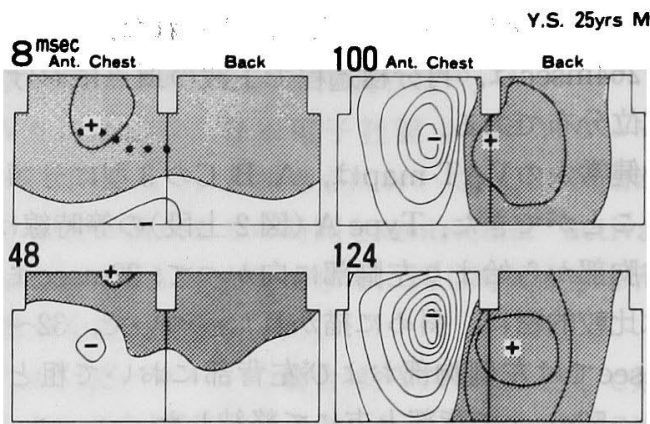

124
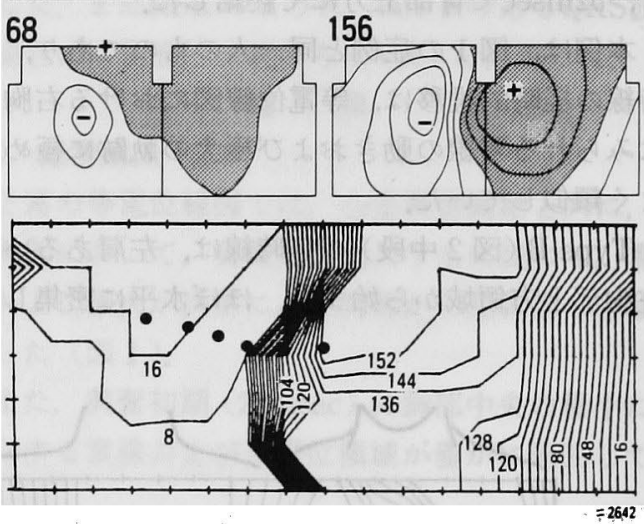

図 4 . 右室心尖部心外膜ペーシングの等電位線図(上) と等時線㘡 (下).
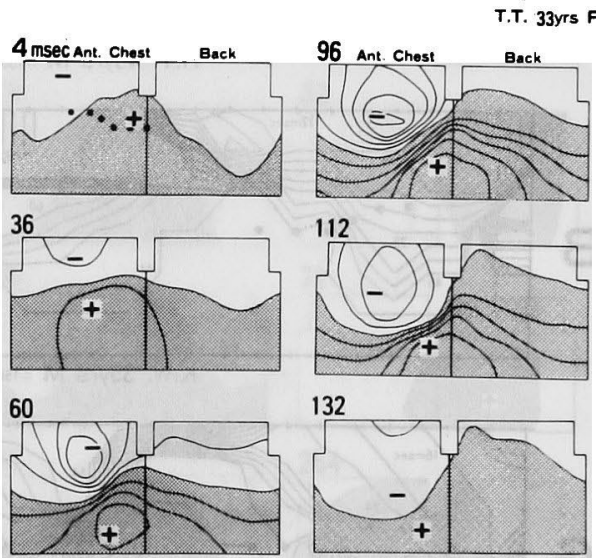

132
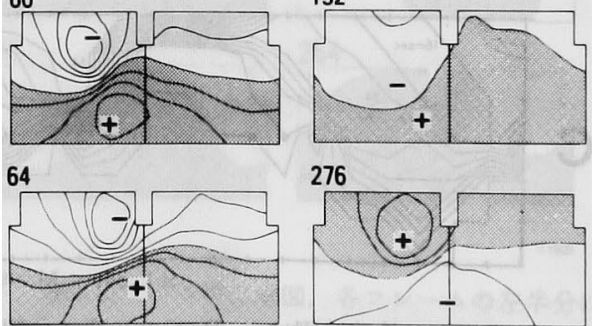

276

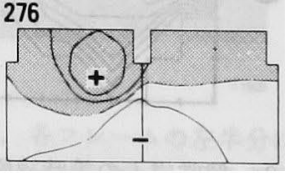

図 5. 右室流出路起源と推定された心室性期外収縮の 等電位線図. 132msecまではQRSであり, $276 \mathrm{msec} は \mathrm{~T}$ 波のピーク時点を示す. 

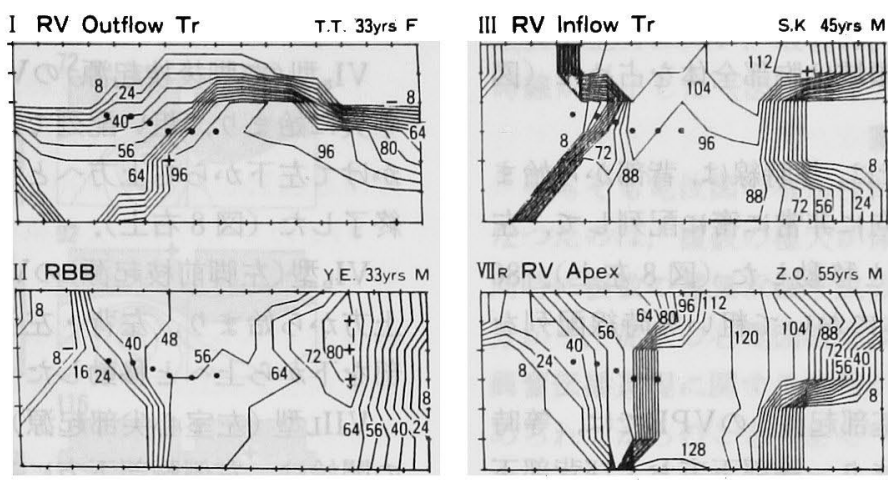

図 6. 右室の 4 箇所に起源を有すると推定された心室性期外収縮の等時線図。 I 型（右室流出路起源）の例は図 5 と同一症例である.

部において縌方向に密集して等時線が配列し，興 奮後期は，等時線は背部にて下方から上方へと進 んだ.

これら 2 例のペースメーカー電位図に拈ける胸 部の零線の動きが, VAT mapの等時線の推移と 極めてよく類似していた。

III. 心室性期外収縮（VPB）

先に等電位線図により発生源が推定された $V P B$ 例の等時線図所見は, 以下のようである.

\section{1）右室源性期外収縮}

I 型 (右室流出路起源) のVPBの等電位線図で は, 胸部上方から極小扣よび零線が水平に徐々に 下方へ移動した（図 5 ).

本例のVAT mapでは, 等時線は胸部上方に始 まり，密な配列で徐々に左側胸部下方へ向かつた (図 6 左上).

この等時線の推移は, 図 5 の等電位線の零線の 動さと極めてよく類似していた.

II型（右脚起源）のVPBの等時線は, 右肩領域 に始まり，おおむ秝方向で，一方は左胸部から 背部へ，他の一方は右背部へと移動した（図 6 左 下). 左胸部から背部にかけての等時線の配列は, 非常に粗かつたのに対し，胸部中央および右背部 のそれは密であつた.

III型（右室流入路起源）のVPBでは，等時線は 右胸部および右背部に始まり，88msecまでは非常 に密集した配列を示した（図6右上）.

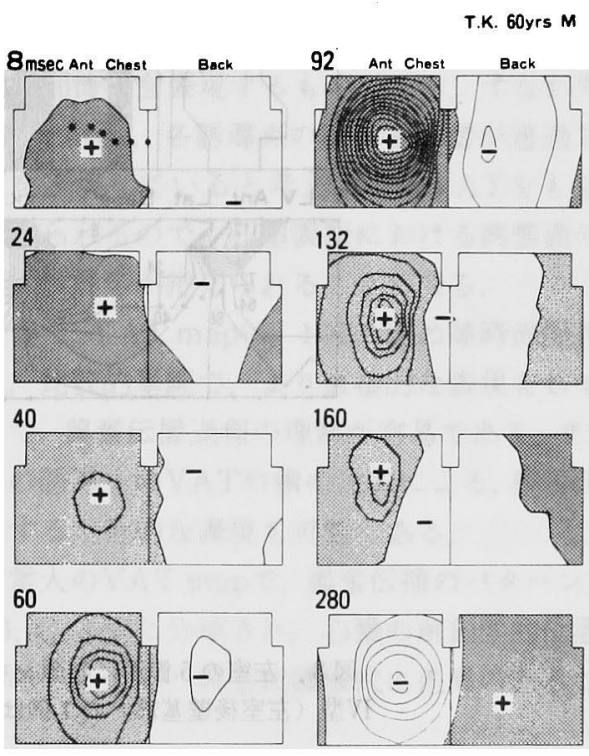

図 7. 左室後壁基部起源と推定された心室性期外収綰 の等電位線図. 160msecまではQRSであり, 280msecは T波のピーク時点を示す.

興奮後期には, 左側胸部から左肩にかけて, 粗 い等時線配列がみられた。

VII R型（右室心尖部起源）のVPBの等時線は, 右側胸部拉よび右背部下方に始まり，密集して左 胸部および背部上方へ向かい，左側胸部で終了し た（図 6 右下）.

2) 左室源性期外収縮

IV型 (左室後基部起源) のVPBの等電位線図で 
は，興奮開始からほぼ終了に到るまで，殆ど常に 負領域は背部を，正領域は胸部全体を占めた（図 7 ).

本例のVAT mapでは, 等時線は, 背部から始ま $\eta$ ，前・中期は程方向に非常に密に配列して，左 胸部之右背部方向へと移動した（図 8 左上）. 80 msec以後は胸部全体に打いて粗い等時線配列を 示した。

$\mathrm{V}$ 型（左室前側壁基部起源）のVPBでは，等時 線は, 左肩領域に始まり, 胸部下方执よび背部下 方に向かい，最終的には胸部中央上方と背部上方
にて終了した（図 8 左下).

$\mathrm{VI}_{\mathrm{a}}$ 型 (左脚後枝起源)のVPBの等時線は, 背部 中央に始まり，粗い配列で左側胸部から前胸部に かけて左下から右上方へと移動し，右胸部中央で 終了した（図 8 右上).

$\mathrm{VI}_{\mathrm{b}}$ 型 (左脚前枝起源)のVPBの等時線は, 背部 上方から始まり, 左背・左側胸部を下行し, 右胸 部を下から上へと移動した（図 8 右中）.

VIIL型 (左室心尖部起源) のVPBでは, 等時線 の開始は, 左側胸部下方にみられ, ついで密集し て左胸部上方および左背部上方に向かい, 最後は,

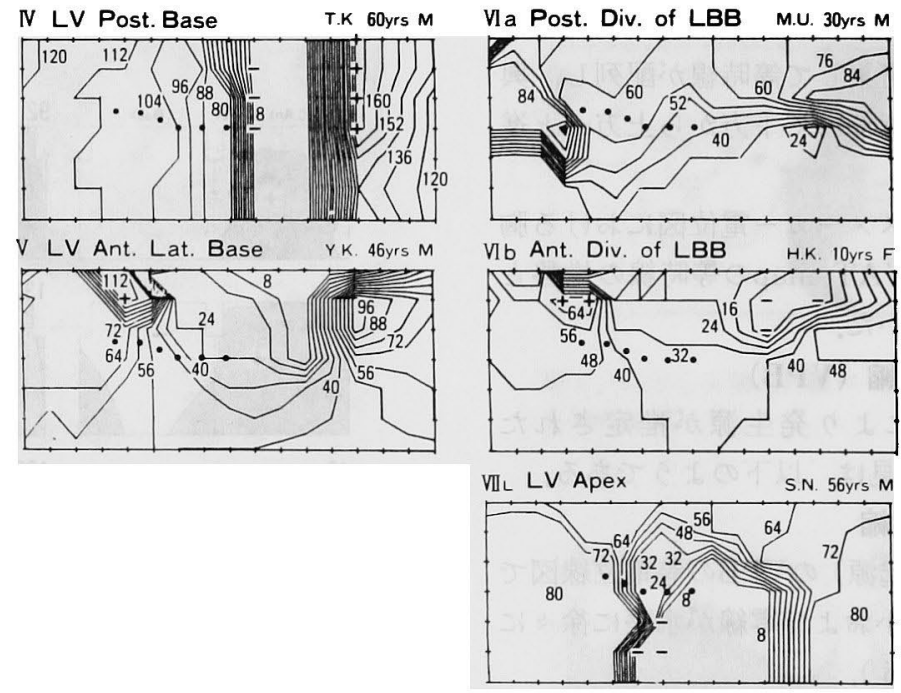

困 8 . 左室の 5 简所に起源を有すると推定された心室性期外収縮の等時線㘡. IV型（左室後壁基部）の 1 例は図 7 と同一症例である.
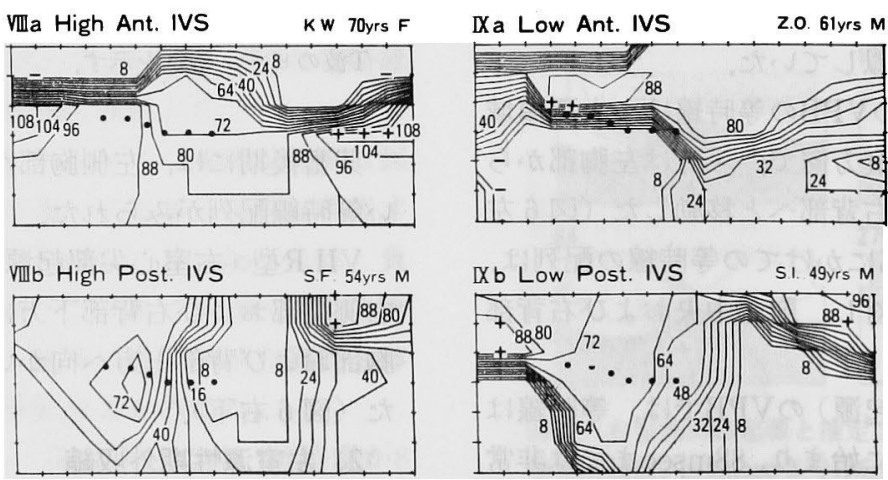

図 9. 心室中隔の 4 個所に起源を有すると推定された心室性期外収縮の等時線図. 


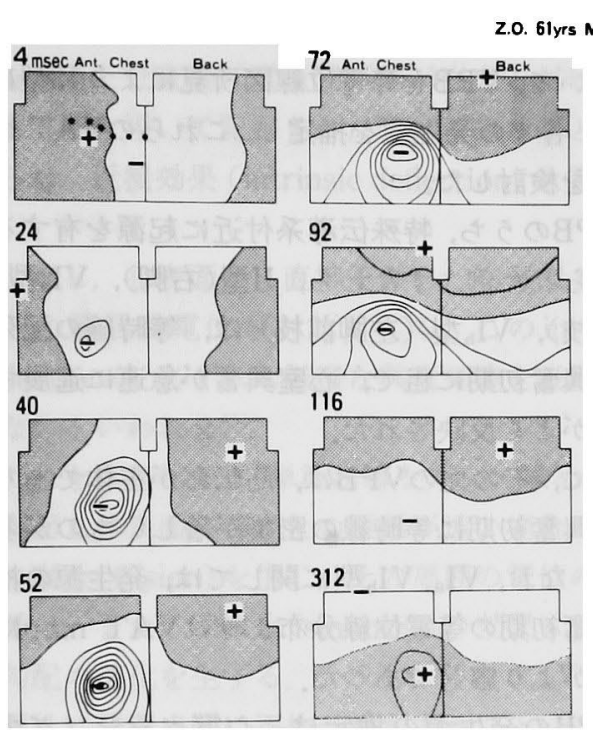

図10。室中隔前下部起源と推定された心室性期外収 縮の等電位線図. 116msecまではQRSであり, $312 \mathrm{msec}$ はT波のピーク時点を示す。図 9 のIX $\mathrm{I}_{\mathrm{a}}$ (心室中隔前 下部）の一例と同一症例である.

右胸部および右背部において終了した（図 8 右 下).

\section{3）中隔起源性期外収縮}

$\mathrm{VIII}_{\mathrm{a}}$ 型 (中隔前上部起源) のVPBでは, 等時線 の開始が胸部打よび背部上方にみられ，初期から 中期には非常に密に配列し, やがて左側胸部を下 行して, 右胸部と右背部へと分かれて進展した(図 9 左上).

$\mathrm{VIII}_{\mathrm{b}}$ 型（中隔後上部起源）のVPBの等時線は, 左背部やや上方に始まり,その後ほぼ垂直方向に 配列して左側胸部および背部へと進展した（図 9 左下).

$\mathrm{IX}_{\mathrm{a}}$ 型（中隔前下方起源）のVPBの等電位線図 （図10）では, 殆ど全ての興奮期に亘つて, 胸部下 方に極小があり, 正領域は52msec以降には胸背部 の上方に位置した。

本例のVAT mapでは, 等時線は胸部下方に始 まり，水平方向に非常に密集して胸背部上方に移 行した（図 9 右上).

$\mathrm{IX}_{\mathrm{b}}$ 型 (中隔後下方起源)のVPBでは, 右側胸部 および右背部下方に等時線の開始を認め,これは,
左胸部上方に向い，最後は，右肩領域において等 時線が終了した（図 9 右下）.

考案

そもそも電位図の有用性が再認識されるように なつたのは, 複数の極大が体表面上に認められ， 同時に複数の電気双極子成分が把えられることが 分かり，従来の心電図法では知り得ない，心臓の 興奮伝播過程に関する情報が提供されることが認 められてからのことである ${ }^{12)}$. 電位図は, 多数の誘 導点からの心藏電気情報を, 二次元的拡がりをも つて時間の関数で処理して提供する。

従来から用いられている等電位線図は, 電位情 報の経時的変化を表わすのに対し，これから派生 して求められるVAT mapは, 電位情報は不問と して時間情報を表現するものである.すなわち， VAT mapは, 各誘導点の直下を興奮が通過した 時点を表現していると考えられるVATをるとに して作られるので, 心室表面における興奮面の体 表面への投影が把えられることになる。

従つて, VAT mapは, 1 枚の図の等時線配列に より，比較的単純で，より直接的な表現をしてい るので, 興奮伝播過程の理解が容易である. また, 特定の誘導点のVATの値の比較による, 興奮伝播 に関する定量的な表現も可能である。

健常人のVAT mapで, 興奮伝播のパターンが, A， B，C 3 型に分類され，心臓の解剖学的位置を も含めて, 正常の興奮伝播様式に差異のあること が示された。

一般に，等時線の粗密は，興奮伝播速度の遅速 と深い関係があるが，興奮面の進行が体表面に対 して垂直方向か，接線方向かにより，体表面への 等時線の投影の様子は異なつてくる. 正常のVAT mapk招いて, 初期の等時線密集は, 心室中隔を 左室側から右室側へ興奮が胸壁へやや垂直に近い 方向で進展するための現象と考えられ，左側胸部 で等時線が粗となるのは，左室自由壁の興奮の進 展が, 胸壁に対して接線方向であるためであろう.

古くから, VATは12誘導心電図上で, 室肥大の 診断の補助として用いられて捛り, 正常値は $V_{1}$. $\mathrm{V}_{2}$ で20〜30 $\mathrm{msec}, \mathrm{V}_{5} ・ \mathrm{~V}_{6}$ で40〜50 $\mathrm{msec}$ された。 
今回の検討で, Typeにより多少差はあるが, 従来 の値と大差はなかつた。

Type A・Cは，等時線の配列方向が右肩から心 尖部に向つて扣り，これから予測される主たる興 奮前面の方向は，12誘導心電図の電気軸と類似し た.

同様にType Bは等時線配列は，ほぼ承平方向で あり，興奮前面の進展が垂直方向に近く，電気軸 もそれに近かつた。

右室心内膜からの興奮が心外膜に到達すると, 興奮のbreakthrough (貫通) が生じ，電位図上で は，零線の正領域への小さな陥凹 (niche) として 表現される ${ }^{12)}$. 従つて, 興奮は，この時点にniche 出現のみられた誘導点の直下に到達していること になるので，本来ならば，niche出現時間とこの誘 導点のVATは同時になる筈である。

しかし, 今回の検討では, niche出現時間の方が 6ー7msec遅れていた.この理由は, nicheとして認 識される等電位線の凹みは, その部位の電極配列 の密度が粗いと遅くなり ${ }^{13)}$ ，なた，nicheを認識す るタイミング,ささらに, 後述するVATの時間の採 り方等の問題によると考克られる.

VPBの多くのものは, 特殊厷導系を用いないで 筋伝導が主体であるので，等時線は泀涪一方向性 に緩徐な進行を示した。このような興奮伝播過程 を追跡する場合は，VAT mapのような等時線表 現は適していると考光られた。

シミュレーション手法を用いた心室興奮层播過 程とVAT等時線図の対応関係の検討で, 興奮伝播 が比較的単純な一方向性を示す心室性期外収縮等 の場合は，両者の所見がよく一致することが確認 されている(1) 16).

しかし，WPW症候群のように，興奮面が同時に 複数の方向に進行する場合や，心電図でRSR パ ターンを示す右脚ブロックの如く，体表面の同一 部位が再度，正領域で占められるようなことがあ ると，等時線が交錯して混乱してしまら ${ }^{17)}$.しか し， $\mathrm{R}^{\prime}$ は局所の伝播遅延を表わす重要な所見であ りこれを等閑視することはできずこれらの問 題に詨しては, VAT mapを興窑前期と後期の 2
枚に分けて表示する等の工夫が必要であろう. ついで，VPBを等電位線図所見により13型に分 類し, 各々の発生源を推定し, これらのVAT map 所見を検討した。

VPBのらち，特殊伝導系付近に起源を有すると 考えられた例，すなわち，II型(右脚)， $\mathrm{VI}_{\mathrm{a}}$ 型(左 脚後枝)， $\mathrm{VI}_{\mathrm{b}}$ 型 (左脚前枝) は，等時線の配列が 特に興奮初期に粗で，心室興奮が急速に進展する ことがよく反映された。

逆に，その他のVPBは，筋伝導が主体であり， 特に興奮初期に等時線の密集が著しいものが多か つた。な拈， $\mathrm{VI}_{\mathrm{a}}, \mathrm{VI}_{\mathrm{b}}$ 型に関しては，発生源の推定 は興奮初期の等電位線分布よりはVAT mapによ る万がより容易であつた。

VPBの発生源の推定は，心室ペーシング中の VAT mapからも明らかなよらに，等時線の開始 する部位とその進行方向，粗密等からなされた。 VAT mapは等電位線図とも密接に関連を有して 扣り，既報泉のように，後者の経時的変化からも， VPB発生源の推定はできたが, 後者によるVPB発 生源の推定の方が，一層直接的表現であるため容 易であつた。

一般に等時線の推移は，等電位線図に扣ける胸 部の零線の経時的推移と極めてょく類似していた が，前者の方が後者に比して時間的により早く進 行した。

今回のVAT mapの作成に当り，興奮到達時間 として，R波の頂点を採用したが，その他の方法 として，基線と交叉する零電位を示す瞬時，また は, minimum derivativeを示す瞬時が採られるこ ともある，この場合，今回の方法の如き，R波の 頂点の瞬時に基づく等時線図の方が，零電位の瞬 時に基づ等時線より進行が先行する.

どの瞬時が興唩伝播をより忠㬰に表現するかの 問題は，まだ電気生理学的螤付けが確立されてお らず，今後の検討が必要である。しかし，前述し たnicheの出現時間とその誘導点のVAT值とのず れは,VATとして零電位の瞬時をとれば少なくな るであろら。

VATは, 元来, 興偣が心内膜から心外膜へ伝播 
するのに要する時間の表現と考えられるが，これ は心表面上で直接，電極間距離が出来るだけ短い 双極電極を用いて記録された時に正確な値として 得られ，近接効果 (intrinsic deflection) と言われ る.

しかし，心表面から直接記録した心電図と，そ の部の膜活動電位を対比しても，このintrinsic deflectionが, 必ずしも厳密な興瞫到達を表現して いないといわれる18).

これを体表面上で, 単極誘導を用いて求めると， 心表面と体表面誘導点との距離が遠い場合は，効 果の融合 (fusion)を生じ，その周囲の電位の影響 を受け，また，平滑化 (smoothing) 効果による電 位勾配の鈍化を生ずる。こうした理由で，VATの 信賴性に誘導点間に不均一性があることは，非侵 襲的な検查法としての限界と思われる ${ }^{199}$.

すなわち，右胸部と背部の等時線の配列の, 詳 細に過ぎる意味つけは避けるべきであろう。

その他の問題点としては, QS, RSR'およびQRS がhigh frequency notchesを示す場合等の時間の 採り方がある。

本研究では，QSの場合，Q波の開始点を採用し たが，これは必ずしもその誘導点直下の興奮到達 を示唆しないこともある。また，再分極過程を推 定することが困難であることもVAT mapの限界 である。

VAT mapkは，こうしたいくつかの限界と制 約があるので，心表面と体表面の順・逆方向問題

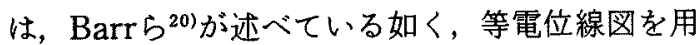
いて展開されるべきであろう。

一方, VAT mapで, 順, 逆方向問題を扱万場合 には，等電位線図の時に大きな問題となる伝達関 数が，それ程問題とならないという利点はある。

以上のよ $5 に, V A T$ mapは, 心臓の興奮伝播過 程を知る上では，1枚の図で，より直接的に表現 できるので，極めて有用な方法と考兄られる。

結論

体表面87誘導点の心室興奮到達時間 (VAT) K 基づくVAT等時線図（VAT isochrone map）を 作成して，心室興奮伝播過程を体表面から推定す
る方法の有用性を検討した。

対象は，健常成人 50 人，心室性期外収縮 (VPB) を有する患者 150 人, 種々の部位の心室ペーシング を行なつている患者25人であつた。

正常のVAT mapは, 等時線配列により 3 型に 分類された。室ペースメーカーのVAT mapで は, 電気刺激部位から進展する心室興奮伝播過程 がよく表現された。

先に我々が等電位線図で推定した13個所の VPBのVAT mapでは，その発生源が明らかに表 現された。

VAT mapは二,三の制約があり，解決されねば ならない問題点もあるが，心室興奮伝播過程を一 枚の図で，より直接的に表現し得て，極めて有用 と考克られた。

\section{文 献}

1) Taccardi B, et al: Chest maps of heart potentials in right bundle branch block. J Electrocardiol 2: 109, 1969.

2) Sugenoya, et al: Body surface potential distribution following the production of right bundle branch block in dogs. Effects of breakthrough and right ventricular excitation on the body surface potentials. Circulation 55: 49, 1977.

3) Yamada K, et al: Body surface isopotential mapping in Wolff-Parkinson-White syndrome : Noninvasive method to determine the location of the accessory atrioventricular pathway. Amer Heart J $90: 721,1975$.

4) Boineau JP, et al: Relationship between ventricular depolarization and electrocardiogram in myocardial infarction. J Electrocardiology $1: 233,1968$.

5) Vincent GM, et al: Diagnosis of old inferior myocardial infarction by body surface isopotential mapping. Amer J Cardiol $39: 510$, 1977.

6) Josephson ME, et al : Comparison of endocardial catheter mapping with intraoperative mapping of ventricular tachycardia. Circula. tion $61: 395,1980$.

7）林 博史，他：体表面電位図による心室性頻拍の 発生源の推定 心電困(別冊)。第 2 回合同学術集 会抄録集，1984，p18.

8）林 博史，他：基礎心疾患を伴わない心室性期外 
収縮の体表面電位図による発生源の推定. 日内会 誌 $73: 807,1984$.

9) Hayashi $\mathrm{H}$, et al : Identification of the site of origin of ventricular premature beats by body surface map in patients with or without cardiac disease. In Advances In Body Surface Potential Mapping, eds. Yamada K, et al The University of Nagoya Press Nagoya, 1983, p257.

10) Uematsu $H$, et al: Ventricular activation sequence in patients with pacemaker implanted at different sites determined by body surface isopotential maps. Proceedings of the VIth World Symposium on Cardiac Pacing. Montreal, 1979, Chapter 2 3.

11) Toyama J, et al : Newly developed body surface mapping system for clinical use. eds. In Advances In Body Surface Potential Mapping Yamada K. et al. , The University of Nagoya Press, Nagoya, 1982, p125.

12) Taccardi B: Distribution of heart potentials on the thoracic surface of normal human subjects. Circ Res $12: 341,1963$.

13）田烟悠，他：電位図上での心室興礑breakthroughの諗識と電極配置. 医用電子と生体工学 $19: 100,1981$.

14) Okajima $M$, et al: On body surface VAT "isochrone" maps generated by computer using simulated excitation sequences in ventricular model. Proceedings of Computers in Cardiology, 1980, 10, Williamsburg, VA, pl87.

15）洞庭賢一：心室内興傽伝播過程推定のための体表 面VAT等時線図の有用性々限界一心室興㽬伝播 シミニレーション手法を用いて一。電图 1 : $160,1981$.

16）洞庭賢一，他：体表面心電図QRS群の興奮到達時 間 (VAT) k関する等時線図と心室興檑伝播過程 の関保一心室模型興䚀伝播ジュレーションによ る研究一医用電子と生体工学 18(特別号)： $618,1980$.

17) Ramsey R III, et al : Comparison of measured torso potential with those simulated from epicardial potentials for ventricular depolarization and repolarization in the intact dog. Circ Res $41: 660,1977$.

18) Sano $T$, et al: Intrinsic deflections, local excitation and transmembrane action potentials. Circ Res $4: 449,1956$.

19）岡島光治：体表面心腀電位因と心外膜興奮层播。 循環器科 $5: 307,1979$.

20) Barr RC, et al : Inverse solutions directly in terms of potentials. In "The theoretical basis of electrocardiology" ed. Nelson CV and Geselowitz DB, Oxford, Clarendon Press, 1976, p294. 